Marquette University

e-Publications@Marquette

Theology Faculty Research and Publications

Theology, Department of

$1-1-2005$

\title{
When Stands Are Taken Where Do We Stand?
}

Robert Masson

Marquette University, robert.masson@marquette.edu

Published version. Horizons, Vol. 32, No. 2 (2005): 203-209. Publisher Link. (C) 2005 College Theology Society (Villanova University). Used with permission. 


\title{
CTS PRESIDENT'S STATEMENT
}

\section{WHEN STANDS ARE TAKEN WHERE DO WE STAND?}

\author{
Robert Masson \\ Marquette University
}

The Vatican took a stand in February with its "notification" on Roger Haight's Jesus Symbol of God prohibiting him from teaching Catholic theology. Then in May it was reported that the Vatican influenced Thomas Reese's resignation as editor of America. In these two situations, as with other recent controversies in the church and American public life, the question was posed to the College Theology Society, "Where do we stand?"1

This is not answered easily. The appropriateness of entertaining the question is itself problematic given the specific ways the CTS constitution defines our mission as an academic society. Has the CTS, its Board or its members at the annual convention any business at all taking stands on controversies in the church or American public life? What would justify this? And to what sort of issues would this apply? And when? How is this decided? And by whom? For whom does the Board speak? Or for whom does a majority at an annual convention speak? And to whom? And to what end?

Nor is the question of where we stand dodged without significant cost. Much is at stake for the specific pedagogical mission of the CTS both in the issues regarding Haight and Reese and in the questions of principle about taking stands. Both are part of a larger and consequential controversy about what place convictions should have in the interactions of the church, academy, and society. The CTS Board has asked me to explain in this essay why and how these issues are of such concern to our mission as professors of theology and religious studies

${ }^{1}$ Issues that have been brought forward recently in resolutions proposed for the annual convention, in communications to the officers, or on the Society's internet discussion listserv include among others: the U.S. war against Iraq, and charges of government complicity in the torture of Muslim prisoners in U.S. detention camps.

Robert Masson, President of the College Theology Society (2004-2006), is an Associate Professor at Marquette University, and specializes in Catholic systematic and fundamental theology. He was Coordinator of the Karl Rahner Society (1995-98) and was Associate Editor of Philosophy \& Theology (1995-2002). The focus of his current research is the role of metaphor and analogy in religious understanding and theological argumentation. 
and to report the actions that the Board is taking consonant with this mission so that our Society might contribute its efforts and expertise to advancing the discussion.

The determination that this essay in our journal Horizons should be the vehicle for an initial response is itself an indication of the Board's view of where we stand. The Society as such is not a "spokesperson" for the Catholic Church. Nor is it a voice of advocacy for whatever theological or religious concerns arise in the church, academy, and society. By and large, our theologically diverse membership is hardly of one mind on such issues. The very rich mixture of perspectives, research agendas and pedagogical approaches is in fact one of the chief contributions of our Society and membership. The CTS is nevertheless a "voice" in the church, academy and culture through its publications, its meetings, and its interactions with American bishops, college and university presidents, and other academic societies. ${ }^{2}$ Moreover, our mission includes "a concern for relating religion to life" and does entail an advocacy for the disciplines of theology and religious studies, particularly with respect to pedagogy. ${ }^{3}$ As CTS President I offer this brief exploratory analysis of where we stand to advance that mission and prompt further dialogue and research among us. When, how and where do we most effectively and authentically exercise our voice?

I do not speak for the CTS membership as a whole. Rather, I speak to the CTS-and to all those who share our convictions about the importance of teaching theology and religious studies effectively and as related to life. On the one hand, we know from classroom experience that genuine learning requires taking stands. Nothing undermines the fruitful engagement of students quicker than evasiveness, obscurity, equivocation or sophistry about where things stand-whether on the teacher's part or the students'. On the other hand, nothing shuts down learning in class more surely than stands taken one-dimensionally, one-sidedly, insensitively, polemically, or coercively-even if only by one party. A similarly destructive polarization and politicization of discourse gravely threatens the possibilities for civic, cultural and religious engagement in contemporary American society and in the church. Of more immediate concern to us as teachers, this rhetorical din and fragmentation undermines the effective engagement of students in theology and religious studies. From this vantage point, there

${ }^{2}$ Over the years there has been cooperation or collaboration, for example, with the Association of Catholic Colleges and Universities, the Catholic Theological Society of America, the International Network of Societies for Catholic Theology, the National Association of Baptist Professors of Religion and the Council of Societies for the Study of Religion.

${ }^{3}$ Constitution and Bylaws of the College Theology Society, Article II, Purposes (http://www2.bc.edu/\% 7Ebarciaus/const.doc). 
is something significant at stake pedagogically and for us professionally in asking "When people take stands, where do we stand?" Although we might not be able to answer with unanimity, our common voice dares not dodge the question lest we become conscripts in building a new postmodern tower of Babel in which it becomes more and more difficult to tell where the truth stands or if truth claims have any standing at all.

To that end, the CTS Board has determined that its conventions and the subsequent publications in 2007 and 2008 will investigate the problem from two perspectives: "Faith in Public Life" and "Catholic Identity and the Laity." For a primary way we address such controversies with a common voice, if not a common answer, is in our concerted efforts in our meetings and publications to probe critically and constructively the stands taken-scrutinizing the presuppositions, parsing the rhetoric, contextualizing the claims, tracing the effective implications, rooting out misrepresentation, and moving understanding forward as best we can. Beyond these investigations at our meetings and in our publications, the Board has appointed an ad hoc committee to develop and propose a clearer protocol to the Society for its handling of public and ecclesial controversies.

There is good reason to ask why any further question of CTS's stand is necessary. The Society devoted some consideration to Haight's book in discussions with him at the 2002 convention, as did our colleagues in CTSA at theirs. In both societies aspects of Haight's project found significant support and criticism. ${ }^{4}$ My own article in the annual volume argued that Haight's approach fundamentally mistakes the logic of orthodox Christology. ${ }^{5}$ The Vatican has taken its stand on the matter now and, it would appear, has not called for a direct response from anyone but Haight himself. There is also reason to question the appropriateness of connecting Haight's situation and Reese's. The circumstances and exercise of ecclesial authority are very different. In the former case, an official, public judgment was rendered; in the latter, information about the case is incomplete and at this point largely anecdotal. Since neither Haight nor Reese are CTS members, what further stake do we as a Society have in these two specific situations?

Our principal stake is in how these events are variously interpreted and how the interpretations shape theological discussion in the aca-

${ }^{4}$ See Anne M. Clifford and Anthony J. Godzieba, eds., Christology: Memory, Inquiry, Practice (Maryknoll, NY: Orbis, 2003) and Tatha Wiley, "Christology Special Session," Proceedings of the Catholic Theological Society of America 57 (2002): 185-87. Unfortunately, neither the CTS annual volume nor the CTSA proceedings include summaries of the questions and observations from the audience.

5"The Clash of Christological Symbols: A Case for Metaphoric Realism," in Christology: Memory, Inquiry, Practice, 62-86. 
demic, ecclesial and public contexts in which we exercise our vocations as teachers of theology and religious studies. The human and historical limitation in taking a stand is that the effect can be different from the intent. This applies as well to the reception of the magisterium's exercise of its pastoral and teaching authority. The polarization and politicization of ecclesial and theological discourse today, at least in American society, has the unfortunate consequence of framing nearly all theological differences as questions either of authority or of incommensurable convictions (often understood as entirely relative ideological options). Too rarely is there an adequate sense that a community of faith is struggling to discern the truth in complicated issues and circumstances. One can rue the role that distortions of the press play in this, but the causes are deeper and the fires have been stoked just as much by rhetoric from all points on the political, academic and ecclesial spectrums.

In this context, where what is at stake is not just the status of particular truths but the possibility of truth as such, it is crucial that the ecclesial and theological pursuit of it not be perceived merely as a play of power and ideology. Too many in our society-even in the church and our classrooms-believe that issues of authority or ideological purity are all that is ever at stake. Then they can go their way, whether identifying themselves as Catholic or dismissing Christianity, without really being engaged at all by the substance of the Gospel truth or the church's witness to it. If we are to rise above the trivialization of religious convictions, then bishops, pastors, theologians and other public voices who take religious stands have a greater burden than ever, not only to articulate what they believe and on what authority, but also to explain patiently and credibly the substance and conceptual rationale for those faith convictions. ${ }^{6}$ It is equally crucial that they create an intellectual and social space, and use it to the fullest, where genuine dialogue on complex and difficult issues can flourish.

America magazine has been invaluable in the United States as a forum that creates such space, that provides nuanced explanations of the church's stands and speaks to such concerns among its readers, and that supports the credibility of the church's convictions by engaging their complexities, difficulties, and counter arguments. It is very unfortunate that stories about Reese's departure have given the impression, at least, that the Vatican disapproves of such intellectual engagement within the church. This undermines credibility of the church's

${ }^{6}$ In speaking of the substance and conceptual rationale of faith convictions, I have in mind the intersection of issues sometimes treated separately in apologetic, fundamental and systematic theology, and related specializations that today are not always so easily or helpfully disconnected. 
convictions and may reinforce the distorted notion that the concern is not truth, but only authority and ideology. The notion that such discussions could be restricted to conversations among scholars is neither feasible today nor responsive to the need in our church and culture for accessible discussion and explanation.

Likewise, despite the controversial character of some of Haight's proposals in Jesus Symbol of God, he is clearly tackling theological difficulties that trouble many in the church and our culture. Haight's book is not the source of these difficulties. Part of what makes it so controversial is that it gives voice to questions and sentiments that already have wide currency and some plausibility. These are issues for many of our students who sincerely seek to understand the substance of Catholic belief. This includes Catholics, as well as those from different faith traditions and non-believers who also populate classes in significant numbers at some of our institutions. These are difficulties, as well, for many of our colleagues in theology, religious studies, and other disciplines who are not Catholic. Nor is Haight the only Catholic theologian for whom traditional ways of resolving these issues are no longer so illuminating or persuasive.

New and creative theological responses to such questions are necessary. It goes without saying that the fidelity of such proposals to the Gospel and tradition is crucial for the integrity of a Catholic theology, and that the bishops and the CDF have a duty to defend church teaching from distortion. But as the long tradition of theological reflection demonstrates, merely stating the church's faith, recalling traditional formulas or underlining the importance of assent to the authority of tradition and the magisterium are not in themselves pedagogically or theologically sufficient. This is particularly important in our context as teachers in American colleges and universities where it is our burden not only to articulate what Catholics believe and on what authority, but also to credibly explain the substance and conceptual rationale for those faith convictions to audiences who do not necessarily share either the convictions or acknowledge the warrants and authorities on which they are based.

The "notification" about Haight's book ought not to curtail discussion of such issues or end further critical engagement of Haight's proposals or with Haight himself. I have found him as a fellow Catholic to be a person of integrity and sincere in his efforts to put forward rigorous and faithful theological responses to these issues. The forum for clarifying disputed questions and overcoming theological error must include as an essential component vigorous and ongoing dialogue and discernment among theologians. This is particularly true if the objective is not merely to state clearly what the Catholic faith holds, but to 
state it in ways that effectively communicate the substance and logic of Catholic convictions to students, colleagues, the faithful and the public.

To a certain extent the CDF action has been counter-productive. Theologians have worried about critiquing Haight's work for fear that their remarks would be used to censure him personally rather than used to further candid analysis and evaluation of his proposals and of alternatives to them. I was asked on such grounds more than once if publishing my own critique was ill-advised. If theologians shirk their responsibility either for mutual criticism or for raising the hard and controversial questions that need to be surfaced, then it will be to the detriment of theology and religious studies and hence of the church. The message for us is to stick to the course of rigorous theological investigation and to do all we can to get better at it. The censure of Haight must not lead to self-censure either in facing controversial questions, in challenging one another's proposals, or in explaining these debates with the required nuance to students, colleagues and the broader public. Unresolved theological issues or resolutions that have been only superficially appropriated fester and threaten greater harm than if they are brought out into the open and constructively engaged.

These considerations have some bearing on the CTS's concern for pedagogy. In college theology and religious studies renewed efforts and more effective practices are required if both communication of the church's stands and the necessary theological engagement with them are to proceed effectively in our classes. As Thomas Rausch observed in The Christian Century, "the question of how theologians teaching in seminaries and undergraduate universities carry out their responsibility to bring students to an adult appreciation of the faith, both intellectually and pastorally, has not always been adequately addressed. It is not sufficient to argue that theology is different from catechesis, as many academic theologians do. Do not these theologians have an obligation to hand on the faith itself and not just the speculations of an academy too often driven by the need to publish? Do they have no responsibility for the religious development of their students?"7 $\mathrm{He}$ notes that while we in the profession have called attention to the religious and theological illiteracy of many young adult Catholics and devoted our pedagogy and scholarship to overcome it, when surveyed at his university the theology majors ironically reported that they "had been better instructed in modern and postmodern developments and critiques of the tradition than in the tradition itself." I do not believe, anymore than I suspect does Rausch, that such anecdotes are evidence

${ }^{7}$ Thomas P. Rausch, "Postmodern Jesus," The Christian Century 122/9 (2005): 31. ${ }^{8}$ Ibid. 
our pedagogical efforts are failing or misdirected. But they point to the ongoing and complex challenge we face today in teaching theology and religious studies effectively at the college level.

In the present context, questions about "where we stand" are best answered by asking how we can use our own voice and voices to create a constructive intellectual and social space within our classrooms, colleges and universities, church and civil society where people of conviction can better discern the truth in complicated issues and in the difficult circumstances of a deeply wounded world. 


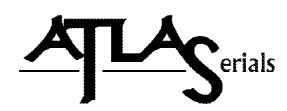

Copyright and Use:

As an ATLAS user, you may print, download, or send articles for individual use according to fair use as defined by U.S. and international copyright law and as otherwise authorized under your respective ATLAS subscriber agreement.

No content may be copied or emailed to multiple sites or publicly posted without the copyright holder(s)' express written permission. Any use, decompiling, reproduction, or distribution of this journal in excess of fair use provisions may be a violation of copyright law.

This journal is made available to you through the ATLAS collection with permission from the copyright holder(s). The copyright holder for an entire issue of a journal typically is the journal owner, who also may own the copyright in each article. However, for certain articles, the author of the article may maintain the copyright in the article. Please contact the copyright holder(s) to request permission to use an article or specific work for any use not covered by the fair use provisions of the copyright laws or covered by your respective ATLAS subscriber agreement. For information regarding the copyright holder(s), please refer to the copyright information in the journal, if available, or contact ATLA to request contact information for the copyright holder(s).

About ATLAS:

The ATLA Serials (ATLAS $®)$ collection contains electronic versions of previously published religion and theology journals reproduced with permission. The ATLAS collection is owned and managed by the American Theological Library Association (ATLA) and received initial funding from Lilly Endowment Inc.

The design and final form of this electronic document is the property of the American Theological Library Association. 